\title{
The Theological Significance of Hegel's Four World-Historical Realms ${ }^{1}$
}

\author{
ERIC VON DER LUET
}

Villanova University

The major problem concerning Hegel's four worldhistorical realms is this: How are we to view them--as categories of historical explanation or as philosophical concepts? Does the Oriental Realm really characterize ancient China, ancient India, ancient Persia, and ancient Israel? Does Hegel's representation of the Greek Realm really apply to ancient Greece? Does Hegel's Roman Realm really reflect the Roman Empire? And does the Germanic Realm really typify the reborn Prussia of the post-Napoleonic era? To be sure, their very names--'Oriental', 'Greek', 'Roman', and 'Germanic'--suggest that they are indeed intended to be categories of historical explanation rather than philosophical concepts.

But it is quite possible, taking these four realms just at their most superficial level and using the posthumous lectures as our text, to show that Hegel's historical categories simply do not fit the historical facts. It is also possible to show that history has not been as simple in the East as Hegel has chosen to depict it. It is easy, therefore, to conclude that because such an analysis of the four realms would reveal many strictly historical inaccuracies, Hegel's philosophy of history carries neither historical nor philosophical merit. Hegel was no historian--and it is certainly true that his philosophy of history severely lacks historical merit--but it is a most unfair and unjustified leap to say also that his philosophy of history lacks philosophical merit. of course, to demonstrate that it does have philosophical merit is a difficult task, much more difficult than demonstrating its lack of merit in other respects.

Hegel made a mistake in naming his four realms after specific geographical regions, for this nomenclature suggests an affinity with certain peoples and with certain historical periods which is plainly not plausible. The names, however, must have seemed convenient to him, since they effectively connected his illustrations with the ideas he wished to illustrate. The historical China, for example, is only an illustra- 
tion--a flawed illustration--and not the basis, of Hegel's idea of the Oriental Realm. Unfortunately. Hegel has immeasurably aided the critic who would claim that, for Hegel, specific historical periods serve as the conceptual foundations, rather than as illustrations, of the four realms. ${ }^{2}$ Hegel would have done much better to have named his four realms after the purely speculative categories which are their true basis, instead of after the historical peoples, periods, and regions which have only some tendency to illustrate human governance in its various aspects of monistic, pluralistic, and dualistic organization.

How do we begin to build the picture of the four realms as philosophical ideas instead of as historical categories? Like so many of Hegel's ideas, the four realms are probably best understood theologically. Indeed his whole systematic philosophy is best understood theologically. John Findlay has asserted that Hegel alone among philosophers has borrowed the entire cast of his thought from Christianity. This means that, in Hegel, there is a creation and a salvation-and that the middle ground between these two poles is history. The world is the arena in which creatures work out their salvation-following the reason provided by the absolute spirit which we call God--and this is a historical process, a logical process with a specified beginning and a specified end, both in eternity. Thus, for Hegel, all history is sacred history, a history of salvation (Heilsgeschichte), the ordered epistrophic process by which God, the Absolute, induces God's creatures to return to God by their own free will, and thus to complete God's own perfection as a concrete universal. It may be shown, elsewhere and with some difficulty, that Hegel's logic, his phenomenological structure, indeed, his entire system, especially insofar as it concerns religion, is founded upon NeoPlatonism--specifically, it is firmly rooted in the traditional Christian Neo-Platonism of Augustine and his successors. But the point to be made now is that Hegel's four realms are only retainable as philosophical concepts if we discard their geographical names and rename them according to their philosophical and theological underpinnings. Toward this end, consider the following schematic representation of the four realms :

1. The Oriental Realm = The Unmediated Monistic Realm.

A. The despotic theocracy of a single patriarchal figure.

B. Religious order and political order are one in form and content.

C. Spirit is bestowed upon people from on high.

D. Abstract universal. 
E. Roughly analogous to Family as the first moment of Sittlichkeit in the Philosophy of Right.

2. The Greek Realm = The Pluralistic Realm.

A. The free autonomy of each individual citizen.

B. Religious order and political order have many forms, but one content.

C. Spirit arises from among the people.

D. Concrete particulars.

E. Roughly analogous to Civil Society in its pure form as the moral expression of the principle of personality, as the second moment of sittlichkeit in the Philosophy of Right.

3. The Roman Realm = The Dualistic Realm.

A. The legalistic heteronomy opposing citizen to citizen, estate to estate, religion to government, etc.

B. Religious order and political order have different forms and contents.

C. Spirit is "dead"--between "Good Eriday" and "Easter."

D. Abstract particulars.

E. Roughly analogous to Civil society in its decay as the second moment of sittlichkeit in the Philosophy of Right.

4. The Germanic Realm = The Mediated Monistic Realm.

A. The ordered ethical theonomy of the entire community and of all of its members.

B. Religious order and political order each have their own forms, but the same content.

c. Spirit permeates, both descending from the universal and rising up from the particulars.

D. Concrete universal.

E. Strikingly analogous to the state as the third and culminating moment of sittlichkeit in the Philosophy of Right.

F. Analogous to the earthly model of the spiritual ekklessia described in the New Testament.

Hegel presents the four world-historical realms in their necessary chronological--or logical--order, according to the necessity of history, $1 . e .$, according to the necessity of Heilsgeschichte, the history of the separation of creatures from their creator, and of their return to that Creator. The oriental Realm is the realm of unmediated monism, to the extent that it is the merely patriarchal situation in which all spirit (Geist) is invested in the person of the father, and in which no-one except the father has any individuality. 
freedom, or personhood. The Greek Realm is the realm of pluralism, the escape from this oriental despotism, where every indivdual free spirit enjoys autonomy. The Roman Realm is the realm of dualism--properly speaking, the dualism of monism and pluralism--the dissolution and breakdown of the Greek Realm, where individual autonomy has proceeded through anarchy and has become merely formal or legal individuality, where the citizen, or some integral aspect of the psychologically bifurcated citizen, is opposed to the political order, the religious order, and other citizens, as an adversary in a bitter, dog-eat-dog world. The Germanic Realm is the realm of mediated moni $\mathrm{sm}$, the resurrected glory from the death and decay of the Roman Realm, the best possible worldly analogue to the Christian ideal of the otherworldly Kingdom of God.

Hegel saw the Germanic Realm as the most adequate, the most concrete, in short, the "highest" of the four on the ladder to the Absolute. On this ladder, beneath the Germanic Realm would come the Greek Realm, then the Oriental Realm, and the Roman Realm "lowest" of all. We can detect the rationale of this ranking from the relation of religion and politics in each, together with the relation of form and content in each, as follows: 1) In the Roman Realm, religion has a different form and a different content from politics, so that the situation entails a profound lack of real unity on all levels. 2) In the oriental Realm, religion has the same form and the same content as politics, but this still does not show any real unity, for this content is unmediated, and in fact is only a "formal" content. 3) In the Greek Realm, religion and politics each have free, amorphous, non-dogmatic forms, but still they have the same content, which constitutes a vast improvement over the Roman Realm toward mediating the content, and thus toward unifying the realm in a concrete way, even though this realm remains inadequate because of its essential disorganization grounded in large measure upon the particularity which at this stage still inheres in the individuality upon which the society is based. 4) In the Germanic Realm, religion has a different form, but the same content as politics, so that the religious establishment and the political establishment are finally unified by virtue of the one truth which they both seek, while at the same time serving as "checks and balances" on each other, working, by virtue of their two forms, against error, tyranny, and one-sidedness in their progress toward the actualization of this truth. This ranking suggests that Hegel values content above form--which is not open to dispute--but values religion and statecraft equally--which is a point debated hotly ever since the time of the Young Hegelians.

Thus, we may see the Oriental and the Roman Realms as essentially opposites: In the former, in which 
religion and politics formally coincide, the unity of content is imposed, not freely or morally chosen by the individual; whereas in the latter, in which religion and politics are distinct both formally and substantively, general social division reigns, and the individual becomes "too free," i.e., "lost" in the sense that he or she cannot realize everything to which a human being is entitled for a happy, fulfilled life. In this realm, the individual is forced by circumstance to choose between serving the political order and serving the religious order, between, as it were, scylla and Charybdis, for it would be impossible to serve both consistently.

The Greek Realm is preferable to both the dogmatic unity of the Oriental Realm and the inevitable bifurcation of the individual in the Roman Realm. The fact that the religion of the polis has a non-dogmatic form prevents theocracy, i.e., prevents religion and politics, the latter having a somewhat more definite form, from coinciding; and the fact that the aims of religion and politics are the same prevents the individual from being confused or disoriented. However, the Greek polis cannot be the ideal of Hegel's state (Staat), since its religion is not Christianity.

The Christian religion, unlike Greek religion, does have a formal structure, and this causes a problem. The analysis of the oriental Realm shows that the forms of religion and politics must not coincide, and the analysis of the Roman Realm shows that they must not differ in content. Thus, in the state, an ideal community, religion and politics must differ in form and coincide in content, in order to prevent both theocracy, on the one hand, and chaos, on the other hand, by the introduction of a form of theonomy. This is the condition which Hegel envisions as typifying the Germanic Realm. The goal of world history (Weltgeschichte) is to estabiish the ethical (sittlich) State, in which two apparently contradictory elements are reconciled, harmonized, and included in toto: 1) the absolute free will of the individual citizen is fully preserved, and 2) strict constitutional laws are laid down in order to protect rights. Historically. laws have generally proven to be hindrances to individual liberty, handed down from the rulers to the people. Hegel, in contrast, envisions his ideal state as arising from and maintaining itself by the free will of each individual citizen. No longer a matter of the citizen bending in order to fit into the stiff mold of the established order, the state will be a free institution designed solely for the purpose of completely fulfilling every citizen's ethical and economic needs. It will not, however, be a democracy; in form it will be somewhat analogous to the Family, a unified community based on love and mutual concern, not an aggregated society based on contract." 
Hegel's ideal of the state based on the unified will of free individuals, instead of on "contract," compromise, or majority rule, is modeled after the ekklessia of the New Testament; and the state is the worldly analogue of the spiritual ekklesia as each stands in contrast to secular concerns and to Civil society. The ethical order of life (Sittlichkeit) characteristic of the state is a theonomy, in which divinely inspired law and right permeate the entire established order. The spiritual content from which the power of the State issues is subjective spirit, or free individuality, reconciled to the divine will--a basis of government which distinctly separates Hegel's theory from that of Rousseau and, somewhat less sharply, from that of kant. The state, for Hegel, is a "strucure of rights," not just a product of history, not just a strong legal or political force, but a Rechtsstaat.

The subjective will is freedom; the good is "the substantial universal of freedom." since their identity cannot be accurately or completely captured by codified law, sittlichkeit cannot be legislated. Indeed, it is love--not agapê, the indiscriminate altruism toward all human beings, but erôs (in the nonsexual sense, of course), the compeling desire for something absent and probably unattainable--which is the real basis of Sittlichkeit. This love is a driving passion for God, erôs for the transcendent, and an equally vigorous patriotic fervor, Volksgeist, which together form the foundation of the state. The great love the citizen has for the state is not fascism, jingoism, or chauvinism, for always God comes first, and God's universal moral law, as in Kant, is always the final authority for human conduct. Hegel was no protoNazi.

The clear distinction in the German language between Gesellschaft and Gemeinschaft has been widely utilized by historians of religion since the sociologist Ferdinand Tönnies formulated the dichotomy systematically in 1887. " Briefly, Gesellschaft is a pluralistic "society" or "association" of individuals in which the primary word is 'I'; whereas Gemeinschaft is a single unified "community" of members in which the primary word is 'we'. Gemeinschaften are typical of religious institutions; Gesellschaften are typical of secular or political institutions. Certainly it would be the exception rather than the rule to find a religious group based on a contractual union, or a secular group based on a spiritual union. In a social organization, Gesellschaft, each member looks after his own interests only. while in an ecclesiastical organization, Gemeinschaft, all members look after one another's interests with equal love and concern.

The Gemeinschaft relationship in Hegel' is not fellow-feeling with regard to the other members of the 
community as individuals. Instead of this one-many relationship, it is essentially a one-one relationship between two individuals of different ontological types. One Individual is in fact the member, but the other "Individual" is the body of whtch he or she is a member.

The two ethical/political theories to which Hegel's Rechtsphilosophie may be seen as a conscious reaction, i.e., Kant's and Rousseau's, each view human interaction in terms of "society" or Gesellschaft, while Hegel believes the best possible ethical/political establishment to be a "community" or Gemeinschaft. The universally guided Gesellschaft is the ideal of Kant, and the freely contracted Gesellschaft is the ideal of Rousseau; but the freely willed Gemeinschaft is the ideal of Hegel. Whereas the fundamental principle of Rousseau's government and of Kant's juridico-civil state of affairs (Zustand) is law, the fundamental principle of Hegel's state is individual free will, which is the Christian and Kantian fundamental principle of morality in general. Law, not fundamental but still important, is sufgehoben in Hegel's state as codified rationality. as constitutional law, and as the fundamental principie of Civil society (birgerliche Gesellschaft).

Note that since all Gemeinschaften are spiritual unions, their fundamental principle must be either theocratic power or free will. since all Gesellschaften are contractual unions, their fundamental principle must be some form of humanly codified law.

Hegel was wise enough to see that theocracy was not the answer to the question of how to make an earthly government which would be at once politically judicious and morally upright. He saw that the ultimate solution could not come down to the people, but had to rise up into the universal from each individual. He saw that for morality to be preserved, free will, the ground of morality, must also be preserved; thus, the state cannot be based on law if it is to be moral. However, since it is a political body, and not purely a moral body, as the earthly ekklêsia would be, law must be included in it, even though not as its basis.

Spiritual life, an integral aspect of God, is for the human individual a Prozess," a movement towards God. To place one's goals in the world of matter or sarx is to deny life itself. Life is a unity, what Hegel calls an Einheit and what the New Testament calls a henotês; whereas the denial of life, i.e.. the denial of the spirit of God, is, in the language of the New Testament, a schisma. Absolute spirit is the union of subjective spirit with God, the Absolute Idea; this union has two forms, earthly and heavenly, each of which may be designated by the New Testament term, ekklêsia: 
Religion, as this highest sphere may be called in general, is to be considered not only as proceeding from and finding itself in the subject, but also, and just as much, as proceeding objectively from Absolute Spirit, which, as spirit, is in the community (Gemeinde) of spirit.'

Religion, therefore, at once unites the believer with God in the heavenly ekklêsia, and just as solidly with his or her fellow believers in the earthly ekklessia.

The dialectical movement of the particular and the universal toward the concrete universal can be identified as the movement of the penultimate Johannine dualism of fleshly plurality and spiritual oneness toward the Kingdom of God. But the end of this movement occurs in the other world; the this worldly end of world history is the establishment of the State, the political embodiment of sittlichkeit, which contains and protects within it the earthiy ekklesia," the religious embodiment of sittlichkeit.

In the genuinely Pauline letters' the earthly ekklessia is described metaphorically in terms of a physical body; however, not only are its members simply "organs" (melos, sing.: mele, pl.) in the body, but they are also individual members in themselves as free human beings. Insofar as each person is tied to God, that person is spiritually one with God; and insofar as such a person is a member of God's church on earth, that person is spiritually one with all other believers. ${ }^{12}$ These two species of oneness are only conceptually distinguishable, for in reality the earthly ekkiessia could not exist without the heavenly ekklêsia, and vice versa. Unless infused with the spirit of God, the earthly ekklesia would be just another earthly Gesellschaft; and, apart from the unified "body" of human believers, the spirit of God would be just an abstract idea of God, lacking concrete realization.

The earthly ekklêsia is a spiritual Gemeinschaft; it is not the equivalent of the institutionalized church(es) on earth. The church member may or may not also be a member of the earthly ekklessia; and the member of the earthly ekklêsia may or may not also be a member of the institutionalized church, though he or she is necessarily a member of the heavenly ekklesia. The earthly ekklêsia, unlike the church, is not mortal, though it is composed of mortals united in their worship of God. The heavenly ekklesia is the eternal spiritual union of immortal souls with their God.

Perhaps the subtle and somewhat elusive distinction can be expressed in this way: Insofar as a person, as an immortal soul, worships God and loves his or her fellow immortal souls, that person is a member of the heavenly ekklêsia; while insofar as a person, as a mortal being, worships God and loves his or her fellow 
mortal beings as subjective individuals, that person is a member of the earthly ekklessia; and insofar as a person is a member of an institutionalized church, that person is a member of a Gesellschaft. The heavenly ekklessia is the ultimate Kingdom of God. The earthly ekklêsia is an image of the heavenly ekklêsia; and the institutionalized church is an image of the heavenIy ekklêsia; and the institutionalized church is an image of the earthly ekklessia. This is the hierarchical organization of the Christian religion, comprising both its this worldly and its other worldly aspects. On the last day mortality will be transfigured and the final Kingdom of God will exist as the heavely ekklêsia, the earthly ekklêsia having been aufgehoben within it.

In the area of political organization there can be nothing analogous to the heavenly ekklesia, which has no earthly form of existence. Consequently, the Hegelian state, 1.e., a Gemeingchaft analogous to the earthly ekklêsia, is as high as political organization can go. Most governments are Gesellschaften, each citizen freely serving only his or her own interests; but in Hegel's state, each citizen freely serves both his or her own interests, insofar as the state contains Civil Society, and the interests of the whole community, insofar as the state is an embodiment of sittlichkeit.

Hegel's sittlichkeit is a kind of theonomy. '3 True sittlichkeit can only be manifested in a Christian Gemeinschaft. Thus, world history demands the move from the fragmented, pagan quasi-sittlichkeit of the Greek Realm to the genuine sittlichkeit which issues from the genuine religion, Christianity, in the Germanic state. But the mere introduction of the Christian kerygma into the world is not enough to accomplish this transition; history must pass through the dialectical phase of the Roman Realm as it moves from the Greek Realm to the Germanic. " Christianity must first stand in direct opposition to the civil government or political order before it becomes freely accepted as the popular religion (Volksreligion) of the new state.

In the Roman Realm, Christianity is a "positive" religion, i.e., it is institutionalized in such a way as to emphasize its objective formality over against its subjective spirituality. In the Germanic state, Christianity will no longer be "positive"--rigid, doctrinaire, static--but rather a Volksreligion like that of the polis. Thus, the power of the Volksgeist manifested in the citizens of the state wili be evident in their religion. Christianity as a "positive" religion is identified with the institutionalized church; as a Volksreligion it is identified with the earthly ekklêBia.'

The history of Christianity thus far has occurred in the context of the "Roman" Realm. This is even true today: Hegel would be the first to admit that his 
"Germanic" Realm has not yet been actualized in history. Though church and government, in the West, are formally separate, they still differ in content; and theonomy, which can be established only by the free act of individual wills unifying the content of religion and politics, has not yet been achieved. If, therefore, the Roman Realm may be metaphorically described as the "Good Friday" of world history, then the Germanic Realm of the theonomic state may be described as its "Easter," yet to come. We are now living on "Holy Saturday."

As the Roman Realm is a dualism between the moral and the political. it is thus analogous to the Johannine dualism between the one, i.e., God, or good, and the many, 1.e., sarx, or evil. And just as evil is constantiy being transformed in the cosmic mythical event of the Christian Transfiguration, and aufgehoben into the heavenly elkklessia; so is the selfishly motivated, godless legalism of the Roman Realm to be transformed in the historical event of transfiguration, and aufgehoben into the Germanic state. In the same way, as the penultimate Christian dualism between good and evil is resolved in favor of good, thus saving the free individual; so the penultimate dualism of the Roman Realm between (Kantian) morality (Moralität) and legalism is resolved in favor of sittlichkeit, thus saving the free individual. With the transfiguration of the Roman Realm, the religious order, no longer the rival of the political order for the loyalty of the citizens, need no longer function primarily as the institutionalized church, but may now freely and openly function as the earthly ekklessia, in harmony with the goals of the newly aufgehoben political institutions.

The Roman Realm, as we have seen, is dualistic, the two poles of the dualism being religion and politics, at odds with each other. The Oriental Realm--monistic--stresses unity and communality or single-mindedness at all costs. The Greek Realm--pluralistic-stresses individual worth and differences. All three realms are aufgehoben in the Germanic Realm, which may accordingly be called a "teleological monism." In the Germanic State, founded on theonomic sittlichkeit, 1) the whole community works toward the same goal (the monistic element); 2) the religious order and the political order work toward the same goal (the dualistic element); and 3) the plurality of free individuals works toward the same goal (the pluralistic element). The final State, as a concrete universal, is an artificial or synthetic monism, i.e., a monistic synthesis of monarchism, individualism, and the dualism between Gemeinschaft and Gesellschaft. ${ }^{16}$

In the Roman Realm no Volksgeist guides or unites the people; this deficiency makes the Roman Realm unique among the four, since even in the oriental Realm there is a sort of Volksgeist. though it is imposed 
from above. of course, the highest, most concrete, manifestation of Volksgeist $1 \mathrm{~s}$, and indeed must be, in the Germanic state.

Hegel refers to the Roman Realm in his Phenomenology of Spirit as a Rechtszustand, a term which in this case, given the abstract, unactualized nature of the "right," is better rendered by 'legal status' than by the more literal 'condition of right'. Hegel's use of the term is fairly derogatory." The idea he wishes to convey is that of a Gesellschaft based entirely on the rigors of codifled law, in which an empty, formalized legalism has thoroughly destroyed any concrete basis of morality. 10

In the Kantian language of Tillich, the basic confict is between autonomy and heteronomy. In one's dealings with God, one is always autonomous and free; but in one's dealings in society one is subject to heteronomous influences and is somewhat compromised, though that person may prosper economically. The individual is unfulfilled when his or her degree of autonomy in the community is reduced, and the community suffers when one individual's autonomy grows to rival the autonomy of others. Thus, individual autonomy and communal heteronomy, which is really an aggregate of individual autonomies, seesaw back and forth in history, with the result that neither the individual nor the community realizes his, her, or its full potential. This "seesaw" process typifies and defines the Roman Realm.

The solution to the constant struggle between autonomy and heteronomy is the creation of a theonomy, or roughly the condition that Hegel imagines was the case in ancient Greece, where a Volksreligion was an integral component of the society. Theonomy is not theocracy, for in the latter only the rulers are viewed as being guided by God's law, while in the former God's law permeates the life of the entire social order. Tillich says that theonomy preserves autonomy in all of its depth for every individual and for the community as a whole. (Theocracy, of course, is an imposed dictatorship.) However, he is pessimistic that such a state should ever come to exist on earth, short of a divine revelation of reason, given the restraining conditions of human existence. 19

Hegel's ardor for Greek Sittlichkeit and Greek Volksreligion seems to have cooled between the time of The Positivity of the Christian Religion (1795) and the time of the Rechtsphilosophie (1820). Apparently, he gradually developed a more sober view of the real conditions in the polis. For example, when Hegel discusses ancient Greece in the Theologische Jugendschriften he does not mention Antigone at all. ${ }^{\circ}$ But in the Phenomenology Hegel says that even though Antigone acted ethically in burying her brother, i.e., in obeying the duties proper to a woman in a sister/brother 
relationship, she is a tragic figure because in performing this primary duty she was forced to neglect her less important duty to her king. Hegel does not expect either her or Creon to feel any guilt. Since she is right with respect to her duty to the family, just as Creon is right with respect to his duty to the political order, to give commands and to expect his subjects to obey them, each is morally blameless as they oppose each other.21 Elaborating on this problem in the Rechtsphilosophie, Hegel places the blame on the structure of the polis itself, and asserts that both family piety and civil authority must be aufgehoben in the truly ethical (sittlich) state, so that they may never be . In conflict and may never contribute to the detriment of the individual, as they were and did in Thebes and, more generally, throughout the Greek and Roman Realms.22 Similarly, all potentially dichotomous moral positions must be aufgehoben or reconciled in the final state.

It must be remembered that the Christian dualism between the monistic spiritual Gemeinschaft and the pluralistic earthly Gesellschaften is only a penultimate dualism, realiy a dualism between monism and pluralism, with the monistic element gradually expanding to engulf the pluralistic element and finally to become absolute in actuality.23

Though Hegel indeed saw people as primarily social beings, he nevertheless refused to see any identification of the actual with the rational outside of the context of Christianity. We may even say that, for Hegel, becoming a Christian means recognizing the presence of rationality in what we see around us: "It is no doubt to be remembered, that the result of independent thought harmonizes with the import of the Christian religion:--for the Christian religion is a revelation of reason. "24"

For the Left Hegelians, rationality is something to be actualized by creating it out of the present situation: Hegel could only call them "adolescent." " But for the Right Hegelians, rationality is actualized by attuning oneself freely to God's foreordained process of unfolding history. Free human recognition of the rational is itself an active process, and has its secular as well as its spiritual or religious dimension.

Religiously, the highest degree of rationality that can be actualized on earth is the earthly ekklêsia; secularly, the highest degree of rationality that can be actualized on earth is the State. The state, the Germanic Realm, will come; it is not up to us to create it. for in its essential rationality it is determined. The "actual and rational" human being is, therefore, philosophically complete, i.e., secularly and religiously, or politically and theologically; he or she is both a citizen of the state and a Christian. Even though Hegel says that the state has no right to inter- 
fere with anyone's religion,--(". . . since the content of a man's faith depends on his private ideas, the State cannot interfere with it"2)--it is still inconceivable to Hegel that the good citizen of the state would not be a Christian. The state can neither be atheistic nor admit of any religion except a "genuine" religion. Of course, for Hegel, the only "genuine" religion is Christianity. The state may not prohibit any single religion; thus, each citizen must become a Christian of his or her own free will if the state is to exist.

Christianity is a variegated phenomenon. In some societies, such as those typified by Hegel as the "Roman Realm," there exists the kind of destructive bifurcation between Christian church and secular government which Rousgeau sees, and which certainly would never be the case under Islam, ancient Judaism, or other theocratic religions. But being a worthy member of either the institutionalized church or the earthly ekklêsia does not entail poor citizenship, does not preclude the establishment of strong and just civil government. The opposition between church and state in the Christian community need not be a permanent historical fact.

Since the dawn of Christianity in the Western world, people have come to expect different sorts of things from the religious and secular spheres. Essentially, this bifurcation constitutes the dualism of the Roman Realm. On the one hand, there is the church, unified and purposeful, but with no concern for anyone's economic well-being. On the other hand, there is the great mass of individuals, isolated from one another, begging for some kind of meaningful national life and a political order to provide for their basic economic needs. As a result, the individual is confused, not knowing whether to starve and be moral, or to eat well and be immoral. Thus, all social order breaks down, as, historically, it did in the conflict between Christianity and Rome. ${ }^{2}$ In essence this is a conflict between the institutionalized church and burgerliche Gesellschaft, as the individual is torn between opposing interests. Between the earthly ekklêsia and Hegel's state, each of them being a Gemeinschaft which resembles the concrete universal. there can be no such conflict of individual interests, since each, founded on free will, tends toward the same end.

This tendency of the Western individual, when thinking or behaving in a secular way, to see the group as an aggregate, coupled with the tendency of the same Individual, when worshipping God, to see the group as a unity, led historicaliy to a situation in which the same individual functioned on two different levels, as a member of 1) the political association and 2) the spiritual community. As Hegel sees $1 t$, there were no 
such problems in ancient Greece, as there were in the early Middle Ages. The Greek polis was pluralistic and individualistic, but the religious community was not a separate estate; it was 1008 in its form but tightly interwoven into the political and social life of the democratic community. Greek religion's lack of dogma and its general flexibility kept the social order from becoming a theocracy, and yet, this "folk religion," so much a part of everyone's day-to-day life, cemented the community together. Since the free individuals of the polis, in Hegel's ldealized view, freely shared so many goals and convictions, Hegel would have had to call this pluralistic community, in spite of its pluralism, a Gemeinschaft.

Raymond Plant makes two additional points: 1) that Hegel probably developed his idea of the "wedge between man gua citizen and man qua child of God" 20 from Rousseau's Social Contract, and 2) that, in Hegel's view, if Christianity had been a folk religion instead of a private religion, such a wedge would never have been formed. According to Plant, for Hegel, Greek folk religion encouraged "social solidarity" and was "the central determinant of the harmony and totality which he considered to be the distinguishing mark of Greek soclety;" "2" whereas Christianity, as a private religion:

- . taught the individual to look beyond and outside the social order in which he lived to find his ideals and values... undermined social commitment . . encouraged the neglect of social and political obligations, the morality present in society... contributed in very large measure to the 1088 of community by stressing inward and private ends as opposed to civic and communal ties."

The conflict of Christianity and the social order is characteristic of the Roman Realm, in which two Gesellschaften, the institutionalized church(es) and the various political institutions, contend for the individual's loyalties. Hegel's basic point is that politics and religion should not be separate spheres in the life of either the individual person or the community at large. Nevertheless, although he sees them as both moving toward the same concrete universal as their goal, he advocates separate earthly manifestations of the religious order and the political order." He is afraid that the spiritual nature of the earthly ekklêsia embodied in the institutionalized church may be perverted by the necessarily secular concerns of the political organization. The state is the union of freedom and law; the church, in its ideal form as the ekklessia, is the union of freedom and divine will. If divine will is allowed to interfere in political deci- 
sions, subjective political freedom will be sacrifjced and a theocracy will ensue. Similarly, if secular codified law is allowed to influence this church in any way, the church's spiritual integrity and the right of its members to worship as they see fit will be jeopardized. It is therefore essential that church and government remain separate to develop normally, each according to its own nature, until the final absolute standpoint is reached at the level of the concrete universal.

Hegel's state and its church differ only in form, i.e., objective, earthly form, but not at all in content. Both desire as their ultimate goal unity and harmony with the universal will. Hegel's State in this teleological way is modelled directly after the heavenly ekklếsia. To have all individuals aufgehoben to the ethical and political level of sittichkeit as citizens of the free state, and to the spiritual level of the Absolute Idea as members of the spiritual body of Christ, is Hegel's goal for humankind, consistent with his basic systematic claim that religion is the proper content of philosophy and that philosophy is the proper form (or expression) of religion."32

Volksgeist. for Hegel, is much more than simple national feeling: it has its roots in Volksreligion and thus is essentially more of a relation between the individual and his or her God than between the individual and his or her country. God, however, is the God of the country as well as of the individual; therefore, there exists a tripartite internal relation anong God, the individual, and the country. We call this tripartite relation Volksgeist, and we call the nation which exhibits this relation among its citizens the state, or the Germanic Realm."

Genuine religion and genuine religiosity emerge only from sittlichkeit. and religion is the thinking sittlichkeit, i.e., the sittlichkeit which is becoming conscious of the free universality (Allgemeinheit) of its concrete essence. Only from and by sittilchkeit is the idea of God known as free spirit; it is therefore vain to seek true religion and religiosity outside of sittlich spirit." 


\section{NOTES}

'This paper is an epitome of my master's thesis, "On the Religious Roots of Hegel's Rechtsphilosophie" (Bryn Mawr College, 1977), directed by Professor George L. Kline, whose generous reinforcement of my efforts has been and continues to be a major source of whatever success I have enjoyed in philosophy.

"For example, the famous "Owl of Minerva" passage in the Preface to the Rechtsphilosophie could easily be misused by such a critic, as follows: If philosophy, for Hegel, is only able to apprehend the past, since the future does not exist to be either known or understood, or even speculated about, then Hegel, in order to be consistent, must himself use the data of the past, specifically, the historical China, the historical Greece, etc., as the conceptual basis of his philosophy of history. If these regions and periods are meant as illustrations of certain types of historical phenomena, then they can only be so used--as illustrations--if they were first the basis of Hegel's conceptions of these phenomena.

'John N. Findlay, Hegel: A Re-examination (New York: Oxford University Press, 1976 ; London: George Allen and Unwin, 1958), p. 354 .

"Cf. Enz.. par. 537. Most of the textual support for the argument of this paper is in the third part of the 1830 Enz., 1.e., Geistesphilosophie, and in the third part of the Rechtsphilosophie, i.e., sittlichkeit.

'Rechtsphil., par. 141.

'Ferdinand Tönnies, Community and Society: Gemeinschaft und Gesellschaft, transiated by Charles P. Loomis, East Lansing: Michigan State University Press, 1957.

'Although Hegel often uses the term Gesellschaft, he does not use the term Gemeinschaft, but rather Gemeinde, which has an equivalent meaning, and which, indeed, he sometimes explicitly identifies with a religious community, e.g., in his Foreword to Hermann Hinrichs' Religion im inneren Verhältnisge zur Wissenschaft $(18 \overline{22})$.

'Cf. Enz., par. 555.

Enz.. par. 554.

${ }^{\circ} \mathrm{Cf}$. Rechtsphil., par. 270, where Hegel is emphatic that the political and the religious orders must 
contain each other, must play counterpoint to each other, and above all, must be completely one in content and completely distinct from each other in form: "Wenn die wesentliche Einheit derselben [d.h. des staates und der Kirche] die der Wahrheit der Grundsätze und Gesinnung ist, so ist ebenso wesentlich, dass mit dieser Einheit der Unterschied, den sie in der Form ihres Bewusstseins haben, zur besonderen Existenz gekommen sei."

$$
\begin{aligned}
& { }^{11} \mathrm{E} . \mathrm{g} ., 1 \text { Cor } 12: 4-27, \text { Col } 1: 18 \text {, and Col } 1: 24 \text {. } \\
& { }^{12} \mathrm{Cf} \text {. Rom 12:4-5. }
\end{aligned}
$$

"Here and throughout this paper, the term 'theonomy' is used in the sense which Tillich established for it in systemat1c Theology.

'Cf. Mt 10:34-39.

"Hegel's idea of the "positivity" of a religion was fully developed in his early essay, The Positivity of the Christian Religion (1795) and was not significantiy altered during his lifetime.

"CE. Shlomo Avineri, Hegel's Theory of the Modern State (Cambridge: Cambridge University Press, 1972), pp. 28-33.

"Cf. J. Loewenberg, Hegel's "Phenomenology": Dialogues on the Life of Mind (La Salle, Illinois: Open Court, 1965), pp. 202- $\overline{06}$.

\section{"Cf. Edward Caird, Hegel (Edinburgh: Blackwood, 1886 [1883]), p. 206.}

"In Systematic Theology Tillich gives the impression that he is very much a Hegelian, an impression not always conveyed by his other books. Certainly Tillich's idea of a theonomy in which the will of God is immanent in all the world derives from Hegel's thought. Each of the concepts in the following passage from Systematic Theology (Chicago: University of Chicago Press, 1951), I, 85, has 1 ts analogue in the Rechtsphilosophie: "Autonomy and heteronomy are rooted in theonomy, and each goes astray when their theonomous unity is broken. Theonomy does not mean the acceptance of a divine law imposed on reason by a highest authority; it means autonomous reason united with its own depth. In a theonomous situation reason actualizes itself in obedience to its structural laws and in the power of its own inexhaustible ground. since God (theos) is the law (nomos) for both the structure and the ground of reason, they are united in him, and their unity is manifest in a theonomous situation." 
2'I.e., neither in the 1907 Tübingen collection edited by Herman Nohl, nor in the 1948 English translation by T. M. Knox (Chicago: University of Chicago Press); nor is she mentioned in this connection in the definitive work on Hegel's juvenile period, Hegel's Development: Toward the Sunlight, 1770-1801 by H. $\mathrm{S}$. Harris (Oxford: Clarendon, 1972).

2'G. W. E. Hegel, Phenomenology of Spirit, trans. by A. V. Miller (Oxford: Clarendon, 1977), p. $284 \mathrm{ff}$.; Phanomenologie des Geistes (Hamburg: Eelix Meiner, 1952). P. 336 f.

${ }^{22}$ Cf. Rechtsphil., par. 166.

${ }^{23} \mathrm{Cf}$. Emil L. Fackenheim, The Religious Dimension in Hegel's Thought (Boston: Beacon, 1970 [1967]), pp. 148-49.

2"Enz.. par. 36 Zusatz. This translation is from Hegel'g Logic, trans. by William Wallace (Oxford: Clarendon, 1975 (1873)), p. 57.

2"Cf. George L. Kline, "Some Recent Reinterpretations of Hegel's Philosophy," The Monist 48 (1964): 48-49.

${ }^{26}$ Rechtsphil., par. 270. Based on T. M. Knox's translation.

2 'Cf. Rechtsphil., par. 357.

2 "Raymond Plant, Hegel (Bloomington: Indiana University Press, 1973), p. 35 .

29 Ibid., p. 34.

"Ibid., pp. 34-35. Cf. also pp. 177-79 on the four realms as a whole.

${ }^{3} \mathrm{Cf}$. Rechtsphil.. par. 270.

${ }^{32}$ Cf. Fackenheim, op. cit.. pp. 160-61, and a note p. 259. While religion and philosophy have the same content, religion has it only in the form of Vorstellung, and philosophy gives it its proper form as Begriff. Cf. esp. Enz., Second Preface (1827).

${ }^{3} \mathrm{Cf}$. Rechtsphil., par. 358-59.

3"Enz. . par. 552. 